\title{
Living in the Shadow of Mainland China: On Delineating Social and Political Constraints Among Southeast Asian Chinese Entrepreneurs
}

\author{
Michael JacobSEN
}

\begin{abstract}
Taking a point of departure in the fluid political and economic landscape of East and Southeast Asia, this paper focuses on ethnic Chinese SME entrepreneurs in Southeast Asia, who are gradually becoming the focus in a discussion of whether a rising Mainland Chinese economy is a positive or negative force in Asia. Contrary to the coherent nature usually associated with this particular ethnic group, this article argues, that in fact it is divided into many smaller factions. This differentiation of the ethnic Chinese community in Southeast Asia, it is argued, is a reflection of many different influences from, especially, colonialism, and different contemporary social and political developments within the individual Southeast Asian countries. This increasing societal complexity makes ethnic Chinese entrepreneurs vulnerable in the wake of a rising Mainland Chinese economy, as they await to see if the latter impacts positively or negatively on the various Southeast Asian economies, thus indirectly influencing how they are embedded within their societies.
\end{abstract}

Keywords: China, Southeast Asia, Indonesia, Malaysia, Chinese entrepreneurship, national politics, ethnicity.

\section{Assessing China's economic impact on Southeast Asia}

According to observers, it is critical for Southeast Asian economies to understand China's economic development, and to understand how to counter potentially devastating and predatory competition from that country. The main background for such a statement is based on the fact that China, in 2002, emerged as the world's largest recipient of foreign direct investment (FDI), thus diverting some of the FDI flows that might otherwise have gone to Southeast Asia (Yeung 2006: 7-8). Furthermore, roughly 75 percentt of China's cumulative incoming FDI has come from Asian economies. Almost 80 percent of all FDI into Asia in 2001 
went to China. China was earlier competing with Malaysia, Thailand, the Philippines and Indonesia, since they were the countries most dependent on foreign investment and technology. However, capital now flows into China, thus restraining the Southeast Asian countries from moving up the value-added ladder. This means that Asian economies with the technical capabilities to stay ahead of China, will benefit from China's economic growth, whereas those that rely on foreign technology, will find their positions threatened by China (Wanandi 2002: 231, Bolt 2000: 111).

Arguably, the economies that will benefit the most from China, are those that can penetrate the growing Chinese market, develop complementary relations with the Chinese economy, attract investment from China and create development partnerships with China. Mari Pangesty adds that given greater openness, growth in Chinese domestic demand, coupled with growth of its labour intensive exports (which are still dependent on raw material and intermediate inputs) certain imports from Southeast Asian countries are likely to increase. These products are oil, gas, wood, rubber, agriculture based products, together with manufactured products such as electrical machinery. Indonesia is a case in point here, due to its large amount of natural resources. It is up to each individual Southeast Asian country to ensure competitiveness when supplying these products to China and so benefit from a rising Chinese economy (Pangesty 2002: 85).

The rising economic power of China, when combined with Japan and Korea, threatens to turn Southeast Asia (except for Singapore) into an 'economic sideshow'. Jusuf Wanandi stresses that it would be wise for Southeast Asia to commit China to a regional web of rules and institutions so as to be able to contain, and partly control, the economic might of China (Wanandi: 2002: 232-33). Mari Pangesty also stresses the importance of creating regional networks based on free trade agreements such as the ASEAN Free Trade Area (AFTA), ASEAN+3, combined with bilateral trade relations between China and each of the different Southeast Asian countries. Compared to regionalism in the Americas and the enlargement of Europe, East and Southeast Asia are still searching for their own institutional identity (Pangesty 2002: 81).

The implication here is that it is imperative to prevent the development of a rigid centre-periphery structure between East and Southeast Asia with all the bilateral patron-client relationships that this entails. From the perspective of Southeast Asia, the means to contain China economically, and to a lesser extent, East Asia in general is thus through 
regional cooperation, where free-trade agreements are the means, and equality in partnership, the goal.

China's ascendance to economic superpower status does not, however, only mean doom and gloom for the Southeast Asian economies. Becoming a big economy also brings with it a growing domestic demand for (imported) goods, and thus an expanding home market. For example, according to Bloomberg News ${ }^{1}$ the Asia-Pacific region exported 44 per cent to China in the 10 months before October 2004, equivalent to US\$219.7 billion. Malaysia alone sent 16.2 percent of its foreign shipments to China in the first half of 2003, five times as much as in 2000. Due to annual growth rates of 8.5 percent in 2003, 9.3 percent in 2005 a further 9.4 percent in 2006 and a predicted 9.5 percent in 2007, China is now the fastest growing economy within the group of ten biggest economies in the world. China is also a new source of income for the developing economies in other parts of Asia.

The Bloomberg News ${ }^{2}$ agency reports that the downside to this, however, is that these growth rates, which attract a huge amount of FDI, may reduce the prospects for growth in such countries as South Korea, Singapore, Malaysia and Thailand,. The combination of low inputs of FDI, and a China oriented export economy, carries the potential threat for at least some of the Southeast Asian economies, in that it makes them even more dependent on China's ability to drive export-led recoveries, thus reinforcing the emerging centre-periphery structure. This potential negative development is, however, more or less outweighed by the acknowledgment that a growing China is also bringing its trading partners along with it.

It is against this background of a fluid, and potentially volatile, economic landscape in East and Southeast Asia, that this paper focuses on one particular ethnic group that has become a centre piece in the discussion of whether a rising Chinese economy is a benevolent or predatory force ${ }^{3}$, that is, ethnic Chinese in Southeast Asia. First of all we have to debunk the general stereotypes applied to this particular ethnic group. Contrary to notions of a coherent ethnic and cultural nature ascribed to this particular group, this paper argues that in fact it is divided into many smaller and non-affiliated fractions both economically, politically as well as culturally. This is due to a question of national loyalty, combined with a host of different economic and cultural preferences in connection with the countries in which the ethnic Chinese reside. Second, this differentiation within the ethnic Chinese community in Southeast Asia, is furthermore reinforced by 
multi-dimensional impacts emanating from colonialism, as well as different types of social and religious constraints found in the different communities and nations of residence. Third, this combination makes the ethnic Chinese vulnerable to the negative effects of a rising Chinese economy, especially those that hit Southeast Asian national economies. For the purposes of this paper, the study will focus on ethnic Chinese who live in Indonesia and Malaysia. Finally, this paper does not centre on major ethnic Chinese controlled firms and conglomerates, but rather on small and medium sized enterprises (SMEs), as they exhibit a greater divide between national loyalties and local constraints, not only towards other ethnic Chinese, but also towards their non-Chinese local and national compatriots.

\section{Chinese Entrepreneurship in a Southeast Asian Context}

The impact of the ethnic Chinese in Southeast Asia has been documented since the $14^{\text {th }}$ century. It was, however, not until the beginning of the $18^{\text {th }}$ and $19^{\text {th }}$ centuries, that migrants and travellers, especially from the southern part of Mainland China, Fujian, Guangdong, Hainan and Guangxi provinces, began in earnest to settle down in Southeast Asia, especially in today's Malaysia and Indonesia. Here they worked as either indentured labourers in the European owned plantation and mines, or settled down as traders of various kinds. These migrants used already existing Chinese networks. These were based on transplanted conceptions of common religious denominations, language or dialect, and descent affiliations together with guilds, which were sometimes organised like secret societies. The common denominators behind these modes of organising were group identification and principles of guanxi, xinyong and kongsi, for example. ${ }^{4}$

In particular, guanxi affiliations appear to be the longest lasting. For example, several observers have argued that guanxi affiliations ${ }^{5}$ within a Chinese network were, and still are, a kind of modus operandi for doing business within the ethnic Chinese business community. ${ }^{6}$ The allencompassing nature attributed to guanxi-affiliated networks is also prevalent in discourses on the Chinese diaspora, that is, the generic name for overseas Chinese networking practices. ${ }^{7}$ For Kotkin (1992), for example, the Chinese diaspora is characterised by an enduring sense of group identification and global linkages, and for Callahan (2002) the comparative advantage of the diaspora's Confucian reading of capitalism, is that cultural ties lower the transaction costs of doing business in 
China and Southeast Asia, compensating for ill-developed legal system in this region. ${ }^{8}$

These perceptions of capitalism in a Chinese context, as constituting a kind of non-grounded transnational flow of ethnic capital, that mainly thrived within close-knit circles, and maintained by age-old Chinese kinship, language or even philosophical affiliations, have an Orientalist feel attached to them. ${ }^{9}$ However, when taking a critical look at the literature on the relationship between contemporary Chinese business enterprises and guanxi affiliated networks in East and Southeast Asia, an absence of a deep influence of the latter on the former, together with a lack of cohesiveness within the Chinese diaspora per se, are revealed. Wong (1998), Gomez and Hsiao (2001) and Jacobsen (2006) all have problems finding evidence for a dominance of chain-related guanxi affiliated business deals within the diaspora, based on ethnic affinities or shared identities.

On the contrary, profit driven motives seem to prevail, be it with intra-ethnic or inter-ethnic business relations, thus also linking up with domestic, non-Chinese, business communities in the host country. This flow between the Chinese diaspora, governed partly by personal strategies and partly by contextual circumstances, is a practice that Riggs (2001) has defined processes of 'diasporisation' and 'de-diasporisation'. This occurs when switching from mono-ethnic to multi-ethnic spatial relations, be they local, national or international Cribb (2000). Gomez and Hsiao (2004) furthermore contest the thesis that the institutions, norms and practices of the ethnic Chinese are the main reason for the growth of their enterprises. Moreover, they question whether Chinese entrepreneurs have depended primarily on business networks based on shared identities to develop their corporate base.

This argument is further expanded by Qiu Liben (2000) who writes that if one examines contemporary Southeast Asian Chinese networks in an historical context, it can be seen that they were not products of the economic and cultural expansion of China, but rather the product of a global capitalist expansion. She continues:

'The Chinese networks themselves have changed with the needs of time; they developed from the networks of bangs (organisations based on guanxi like connections, MJ) to the networks of the overseas Chinese and then to the open and multi-cultural networks shared by citizens of various countries. This has enabled them to play an important role in the sustained economic development of Southeast Asia and in integration of the region' (Qiu 2000: 203). 
This confirms Arif Dirlik's (1996) proposition that guanxi business practices are an 'ethnicisation' of universal capitalist practices and not specifically Chinese economy paralleling global capitalism. Returning to the discussion of the cohesiveness generally attributed to the Chinese diaspora, this paper agrees with the idea that a diaspora constitutes a decentred, multi-levelled and fractious, generally ethnically affiliated, ideational network which allows people to move in and out of a given diaspora depending on their current social and political situation. ${ }^{10}$ The adherence to a perceived relevant diaspora thus depends on relative social, economic, and political contextual givens. An understanding of a given diaspora does therefore not depend on systemic network approaches. That is, theoretical constructs underpinning the empirical and geographical constraints, as indicated by Ong and Nonini (1997), but rather by analysing de facto socio-political contexts, that delineate the positioning of an individual in an appropriate diaspora. By taking such an approach, it is imperative to focus on those social, political, and economic forces that have the capacity to generate changes in the societal embedding of the ethnic Chinese.

\section{Home Country or Country of Residence? Chinese Entrepreneurs and the Dominant 'Other'}

The above discussions, result in the main question asked in this paper: having disentangled Chinese network practices and having stressed how imperative it is to focus on the social, political, and economic factors that have a capability of generating changes in the societal embedment of the ethnic Chinese, how have the ethnic Chinese have reacted towards the growing Mainland Chinese economy? Arguably, by focusing on ethnic Chinese SMEs and stressing the importance of analysing them in relation to their societal embededness, the importance of the Mainland Chinese market comes second to those entrepreneurs. They have to secure primarily their freedom of manoeuvre in their communities of residence, a freedom that is guided just as much by social and cultural strategies as by cynical economic calculations or emotional or ideological attachments to 'the old country'.

This argument becomes more important as the rising Mainland Chinese economy influences, positively or negatively, the economic performances of the various countries in the Southeast Asian region. Moreover, this again influences the domestic attitude towards the ethnic Chinese in 
their respective communities of residence ${ }^{11}$. Arguably, the ethnic Chinese in Southeast Asia do not unilaterally embrace the expanding Chinese economy, as it has a certain impact on their freedom of manoeuvre in their communities of residence. Instead we see a careful balancing of how to achieve the better of the two worlds, which result in the increased potential for expanding one's business without jeopardising the relationship to the dominant non-Chinese social and political environment.

Before further discussing this through two case studies (both from the provincial capital Manado in North Sulawesi Province in eastern Indonesia and from Johor Baru in the State of Johor in southern Malaysia), the paper highlights an important non-economic concomitant effect of an economically strong Mainland China, namely a further visualisation of the Southeast Asian Chinese conceived of as a minority group in the respective countries of residence, a visualisation that carries the potential for a further negative stigmatisation of this already exposed group. Here the discussion refers to the relationship between a generational conditioned division within the ethnic Chinese communities themselves, namely a distinction between peranakan and totok ethnic Chinese. This generational conditioned is reflected in the fact that peranakans have lived for five to six generations in Southeast Asia, whereas totoks have mainly one or two generations behind them in a Southeast Asian context. As the latter has much closer relationships to Mainland China than the former, a process of re-sinification is taking place between the two categories of ethnic Chinese, a process that is fuelled indirectly by a growing economic impact from Mainland China. As this has a destabilising effect on the relationship between these two groups, a further differentiation within, and additional visualisation of, the different ethnic Chinese communities is gradually taking place in their respective countries and communities of residence. The following discussion draws mainly on Indonesian material, but some more general political and economic ramifications of this problem, for the ethnic Chinese across the Southeast Asian region will be considered.

In Indonesia and Malaysia, peranakans were formerly known as Baba, or early immigrants to the region. Babas used their local position to claim higher status compared to the Sinkeh, the newly arrived Chinese immigrants (Tan 1997: 25-6). A derogative usage of the term Baba can be found when coupling it with the term Ali. Ali-Baba refers to a joint Indonesian-Chinese business venture, or more specifically, to an Indonesian front figure or sleeping partner in an enterprise owned and financed by an ethnic Chinese. 
According to William Skinner (1996: 78-9) peranakan refers to those ethnic Chinese who have developed a creolised or mestizo-like culture with strong Indonesian characteristics. The most important characteristics of the peranakans were, and still, are that they marry local Indonesian women and speak Bahasa Indonesia within the family. Proficiency in Chinese languages and knowledge of traditional Chinese culture has gradually disappeared and today, most peranakans do not speak, read or write Chinese.

The other main group of Indonesian ethnic Chinese is the totok. This term refers to 'full-blooded' Chinese in Indonesia. They are relatively recent immigrants or children of recent immigrants, who speak one or two Chinese languages, and practice traditional Chinese customs within the family (Skinner 1996: 86, 88-92). The totoks generally represent Hokkien, Cantonese, and Hakka speaking areas in Southeast China. Speech-group identification is an important means for identifying group membership. Because of laws implemented by the Indonesian government in 1959 and onwards, forbidding non-Indonesian people to engage in retail trade outside towns, many Totoks moved from the Outer Islands to the commercial centres, especially around Jakarta and the other main cities in Indonesia, where some of their most important markets were.

Leaving aside this distinction for a moment, the Indonesian authorities and the society in general, have always been ambivalent towards the ethnic Chinese, peranakans and totoks alike. This can be observed by studying the anti-Chinese riots through Indonesian political history. Here the paper alludes to comparison of negative social, economic, and political developments with the appearance of anti-Chinese riots. A main precondition for this correlation is that the ethnic Chinese are generally conceived of as a foreign minority, and are thus classified as non-pribumi or 'not sons of the soil', that is, non-indigenous people. Furthermore, international political developments have also helped in fuelling anti-ethnic Chinese resentments within the Indonesian community, thus reinforcing the above mentioned grievances towards the ethnic Chinese.

For example, in the early 1950s, the newly established communist government in Mainland China opened an embassy in Jakarta's Chinatown, which was followed up by a number of consulates in other major cities throughout Indonesia. The diplomats were very active in contacting the ethnic Chinese. This resulted in a 're-sinification' of the Chinese communities in terms of an increasing flow of Chinese literature, the opening of many Chinese language schools, and a resurrection of 
Chinese religions, together with the building of temples throughout the country. The main aim of these activities was to help establish the ethnic Chinese as a recognised ethnic group that was on an equal footing with other ethnic groups in Indonesia. It was thus a process of integration and not one of assimilation.

These developments brought the Chinese communities to public attention, and questions of political loyalty and national belonging became a hotly debated topic. According to Mely Tan (1997), of the 2.45 million ethnic Chinese believed to live in Indonesia during the 1950s, about one million could be considered having dual nationality, that is, having citizenship in both Mainland China and Indonesia. In order to correct this, the Indonesian government decided to force the ethnic Chinese to make a choice between citizenship in one or the other country. This resulted in the Sino-Indonesian Treaty on Dual Nationality, signed in Bandung on 22 April 1955, when it was decided that ethnic Chinese had to choose which nationality they preferred during the period January 1960 to January 1962. Most of the about one million ethnic Chinese with dual nationality registered and out of those about 65 percent opted for Indonesian citizenship. In practice this meant a huge exodus of ethnic Chinese, about 400,000 people, from Indonesia, heading towards the new Chinese nation (Tan 1997: 33-5).

However, problems for the ethnic Chinese had, only begun. In 1957, the authorities demanded that all Indonesian citizens attended Indonesian schools. This meant that thousands of Chinese schools were closed. The period around 1965-6 was a particular difficult one, as many Chinese were killed and driven out of, for example, Aceh, North Sumatra, and the rural areas in west Kalimantan. The main reason for this was that it was thought, especially by the political elite and the military, that the ethnic Chinese were collaborating with the Indonesian Communist Party (PKI) and that the first president Sukarno was relying too heavily on the Chinese and PKI for political support.

This situation further changed when President Suharto's New Order regime (1966-98) replaced what was left of Sukarno's Guided Democracy in 1965. The new regime initiated an intense programme of assimilating the ethnic Chinese into the Indonesian community by forbidding Chinese names, signs in Chinese characters in public places, publications, cultural and religious practices, constructions of new temples, etc. so as to domesticate and pull the Chinese into mainstream New Order Indonesia. Nonetheless, despite these assimilatory initiatives, the ethnic Chinese were still discriminated against both in terms of education (they 
could not join the majority of universities) and could not get employment in the bureaucracy and military. Even the most assimilated ethnic Chinese were marked out, as all Chinese had a code in their passport indicatung they were of Chinese descent, and thus not 'blue-blooded' pribumi Indonesians. ${ }^{12}$

After President Suharto was toppled on 21 May 1998 things changed again. The interim president Habibie and the following two presidents, Abdurrahman Wahid and Megawati Sukarnoputri, allowed the ethnic Chinese to practice their traditions, especially the Chinese New Year, learn Chinese languages, publicize newspapers and books in Chinese, and generally make Chinese culture more visible in Indonesian society. The forced assimilation programme was thus formally abolished. This new zeitgeist was seen in a presidential decree issued in 1998, that instructed ministers and chiefs within the bureaucracy to scrap all discriminatory practices against the ethnic Chinese. In May 1999 Chinese initiated political parties such as the Chinese-Indonesian Reform Party were formed, and the renowned economist Kwik Kian Gie became deputy chairman of Megawati Sukarnoputri's Indonesian Democratic Party of Struggle (PDI-P). Later on the same year, he became Coordinating Minister for Economy, Finance and Industry in the Abdurrahman Wahid/Megawati Sukarnoputri administration. He was thus the first ethnic Chinese to attain a ministerial portfolio in the post-Suharto era. After sizing power in July 2001, Megawati Sukarnoputri's administration, represented by the Minister of Religious Affairs, issued Decree No. 13 stipulating that Imlek or the Chinese New Year was a public holiday. The inauguration of the current Indonesian president Susilo Bambang Yudhoyono, who took office in October 2004, has seen a continuation of the ethnic policies of the previous presidents, thus furthering the establishment of the Chinese as an integrated part of the Indonesian society. On the basis of these changes, life for the Indonesian ethnic Chinese has become somewhat easier.

These changes, however positive they may be, also pose new challenges for the Chinese communities. The remaining discrimination against them, especially in terms of obtaining Indonesian citizenship and having to state their ethnic origins in their passport, still lingers on, not forgetting the general anti-Chinese sentiment in Indonesian society, encouraged by the New Order regime through the years it held power. What is more problematic, however, is a growing split within the ethnic Chinese community itself, a split that revolves around the question of identity. Although not an entirely new problem, the ques- 
tion of how to designate themselves has particularly come to a head in the post-Suharto era. Labels such as Overseas Chinese, Ethnic Chinese, Chinese nationals or Nationals of Chinese Descent have been applied to the ethnic Chinese, not only in Indonesia, but throughout Southeast Asia, indicating a tense relationship amongst the ethnic Chinese, their respective nation states, and their relationship to Mainland China thus turning an ethnic label into a problematic political signifier. For example, Leo Suryadinata (1997: 20) writes that for recent migrants their ethnic identity is stronger than their national identity. This is not a problem when Mainland China's relations with the individual Southeast Asian states are cordial. However, when China-Southeast Asian relations turn sour, as in the case of, for example, the Spratly Islands issue, then the ethnic Chinese generally become the focus of resentment from the indigenous populations.

The tendency in many parts of the region to classify the ethnic Chinese as nationalized foreigners with a doubtful political loyalty towards their respective community of residence, also poses tremendous problems for the ethnic Chinese themselves. If labelled 'Overseas Chinese', they are not thought of as true nationals in their community of residence, only visitors with perceived strong ties to Mainland China, who might pose a national political threat. If individuals are labelled as 'Ethnic Chinese', and with many generations in their community or residence behind them, then they are more or less socially and politically marginalized. This can be seen especially in Indonesia, Malaysia, and the Philippines. The dual nature of the ethnic Chinese identity thus represents a national security liability. As a counter move towards such negative stigmatisation, Tan Chee Beng (1997: 29) states:

'Overall, the Chinese in Southeast Asia should not be called "Overseas Chinese" as it is a label which is appropriate only for citizens of China living overseas'.

He continues:

'As proud citizens of our respective countries, we feel insulted to be called or even referred to as "Overseas Chinese". We are overseas in China but not when we are at home in Malaysia, Indonesia, the Philippines, and so forth' (Tan 1997: 25).

The main question here is whether the Southeast Asian states will let the ethnic Chinese themselves decide how they prefer to be labelled. As we have seen in the case of Indonesia, the foundations of this lie within national politics that decide what label to apply to the ethnic Chinese. 
Parallel to these external discourses, internal divisions from within the ethnic Chinese communities themselves are gradually surfacing, the previous distinction made between peranakans and totoks.

Today the relationship between peranakans and totoks highlights the heterogeneity of the ethnic Chinese community. They have never been a homogeneous group as maintained by Suryadinata (1997), as the ethnic Chinese reflect different social and political circumstances in their respective communities of residence, as well as different circumstances under which they became ethnic Chinese in a Southeast Asian context. The continued difference between peranakan and totok Chinese thus represents a deep differentiation of the ethnic Chinese community. The first stands for assimilation into the communities of residence, the latter, trying to accommodate policies of assimilation, but with due respect towards Chinese culture and traditions.

This leads us back to the main thrust of this paper, namely how an economical powerful Mainland China is being perceived by the ethnic Chinese communities in Southeast Asia. For example, in the shadow of Mainland China's ascendance towards economic superpower status, totoks try to're-scinicise' peranakans and to make them acknowledge their ethnic and cultural background, thus making them more visible as a distinct ethnic group in relation to other ethnic groups in the host community. The reason behind this strategy, is to put them in a better position to link up to Mainland Chinese' domestic markets through, for examples, diasporic linkages, or to act as guanxi or go-betweenpartners to either bumiputra or pribumi economic parties, in Malaysia and Indonesia respectively, with a similar interest in entering Mainland Chinese markets.

This strategy might, however, backfire on the ethnic Chinese communities themselves. Apart from the possibility of generating a further negative stigmatisation of the ethnic Chinese per se, as those who are in charge of initiating economic revitalisation at the expense of the indigenous entrepreneurs, it might also increase tensions between the two groups, especially as the peranakans have deep-rooted vested interests in the local communities. In fact, these vested interests are their insurance for a positive acceptance by the 'dominant other' in their community of residence. Ultimately, the totok initiated 're-sinification' initiative carries the potential negative impact that the host communities become even more suspicious towards the ethnic Chinese in general: what are they up to, whom do they represent, and are they really the loyal citizens they claim to be? 
The paper now turns to two small case studies of ethnic Chinese SME business communities in Manado, the provincial capital of North Sulawesi, Indonesia, and in Johor Baru in the State of Johor, southern Malaysia. In particular, it will focus on how they relate to their respective communities of residence and whether the current economic events in Mainland China have any influence on their current economic performance.

\section{On the Societal Embedding of Southeast Asian Chinese Entrepreneurs: Two Case Studies}

\section{Manado in North Sulawesi Province, Eastern Indonesia}

Two things stand out when studying the Manadonese Chinese Business community. The first is a high emphasis placed on assimilating into the Minahasa community ${ }^{13}$, a preferred societal positioning that is underlined by referring to oneself as a peranakan. Stressing assimilation instead of integration and categorising oneself as peranakan, is similar to stressing both a diachronic and synchronic sense of belonging. Being a peranakan emphasises having roots in the local community and being assimilated refers to an abolition of ethnic differences. At face value, these two main aspects of being Manadonese Chinese could be one of the factors that explain why there have not been any violent clashes between ethnic Chinese and the Minahasa before, during and after the fall of the New Order regime.

The second thing about the Manadonese Chinese is that they do not stand out as a distinct ethnic group among the Minahasa. On the contrary, even the Minahasa stress the almost total assimilation of the Chinese into the local communities. It seems as this can, to a certain degree, be attributed to the fact that the mechanisms for marking oneself out as a distinct group do not influence the current inner functioning of the Manadonese Chinese. For example, guanxi affiliations do not play an important role within the ethnic Chinese business community even though they can still be identified as a social signifier amongst the Manadonese Chinese. As such, this study subscribes to Gomez and Hsiao's critique of guanxi practices in a modern economy. As previously stressed, it is the profit motive that plays the greatest role for the Chinese entrepreneurs when conducting business, not ethnic factors or cultural preferences, a fact that also goes for the Manadonese Chinese entrepreneurs. As a result, the paper argues that Dirlik's point that guanxi is more about a 
rhetorically dictated ethnification of capitalist practices, is not a practical one. Kongsi practices and guanxi affiliations are thus only invoked if they can lead towards higher or more stable profit margins. In this sense, continuing to stress guanxi as a dominating aspect of Chinese business practices, in at least Manado, can be categorised as a kind of cultural chauvinism within a specific business environment.

An interesting consequence of the non-dominant position of guanxi in the Manadonese Chinese business community is that, because it is so weak, it actually undermines the functioning and effectiveness of kongsi organised businesses. Arguably, guanxi affiliations can be conceived of as reinforcing the inner workings of kongsi organised businesses, as both strive towards reinforcing relations between the Chinese partners and thus indirectly promote a distinct Chinese-ness in terms of business practices. However, guanxi only constitute but one out of several business strategies when establishing kongsi based companies. This de-linked relationship between guanxi and kongsi therefore reinforces processes of assimilation and down plays the development of a distinct ethnic identity. Such a development is reinforced by yet another factor, namely religious affiliations. Christianity, the dominant religion in North Sulawesi, is generally seen as a facilitator between non-Buddhist Chinese and Christian Minahasans. Christian Chinese by far outnumber Buddhist Chinese, so processes of assimilation are further reinforced.

However, taking processes of assimilation to their ultimate limits, leads towards the assumption that ethnically distinctive features become hybridised to such an extent that the original ethnic identities involved are gradually dissolved and a new, commonly agreed upon cultural denominator, arises. Such a perspective can only be an illusion. Assimilation processes are always based on asymmetrical relationships. In the case of the Manadonese Chinese and the Minahasa, the latter is the dominant half, and it would be difficult to imagine that they would give away any of their perception of ethnic supremacy in relation to the ethnic Chinese. As such, assimilation processes are about stipulating power relations that are manifested in social integration and more or less peaceful co-existence. Ethnic distinctions remain despite these processes, but descend towards a lower level of social practice. They only resurface during ceremonial occasions, which are socially detached and socially accepted by the dominant 'other'.

A somewhat unexpected consequence of these processes is that the Manadonese Chinese become separated from the Chinese diaspora. By far the greatest numbers of informants have detached themselves from 
their ancestral root in either Fujian or Guangdong Province. Mainland China is currently being conceived of as either a potential promising target for doing transnational business, or as an interesting tourist destination. The 'home' part of the Chinese diaspora has thus been separated from the otherwise classical triangular perception of diasporic constellations, namely the 'home-host-migrant' construct. This points towards the fact that diasporas are multi-dimensional entities that are contextual defined. Even though the Manadonese Chinese have currently cut off the 'home' part of the Chinese diaspora, the linkages are still there, but dormant. This means that when not activated, diasporic links descend into a deeper layer within peoples' minds, and remain there until various social and political events jolt them back into existence.

On the basis of this, it is possible to say that a diaspora is a latent structure, that is, not a permanently established ethnic oriented national or international path for migrants and travellers. A diaspora only becomes alive locally when certain social, political or economic events highlight or squeeze a certain ethnic group. This confirms Riggs's (2001) notion of diasporasation and de-diasporasation as people utilise a given diaspora when they need it., otherwise it does not exist for them. North Sulawesi provides them with a social and political safe heaven, and the Minahasa accepts the Chinese in their midst as they constitute an important economic factor in the province. Therefore, the Manadonese Chinese are highly localised, that is, 'assimilated' and thus de-linked from the Chinese diaspora. For how long these positive inter-ethnic relationships will last, depends on a whole range of things from economic performance, locally as well as nationally, to religious harmony, and amicable and non-competitive inter-ethnic relationships. When and why a shift in these relationships might occur, thereby giving rise to a potential relinking of the Manadonese Chinese to the Chinese diaspora, can only be determined through empirical studies, not theoretical predictions. ${ }^{14}$

\section{Johor Baru in the State of Johor, Southern Malaysia}

Contrary to the Manadonese Chinese entrepreneurs in North Sulawesi, there is a clear perception among the ethnic Chinese SME entrepreneurs in Johor Baru (JB) of being distinct from other ethnic groups in the state of Johor, and of being treated accordingly by the community of residence. The blame for this state of affairs is laid on the official bumiputra policy that favours the Malay population at the expense of the Indian, and in particular the ethnic Chinese, population. A consequence of this policy is an official discrimination against them: Malaysian people got most 
of the public benefits in terms of education and financial support from the government, both the state and national governments. Seen from an ethnic Chinese point of view, they are more or less left to care for themselves. In terms of education, this results in most Chinese students going abroad or attending the many private schools and higher education institutions to be found throughout Malaysia. There are several in JB, but many young people prefer to cross the Johor Strait in order to get their education in Singapore. The negative consequence of this is that many do not return to JB, but choose instead to settle down and marry in Singapore.

As can be seen, the relationship between ethnic Chinese and the bumiputra are not governed by policies of assimilation, but rather by a policy of a peaceful co-existence based on a framework of mutual interdependency. In a sense, this relationship is perhaps more honest,, as it is not dressed up in a rhetoric of assimilation, as in North Sulawesi. This proves the previous view on the relationship between integration and assimilation, in that the latter is but a 'cover up' for an asymmetrical power relationship between the two groups. In JB, this power relationship is by no means covered, but played out in the open. Due to the officially sanctioned practice of ethnic discrimination, not only in the state of Johor but throughout Malaysia, ethnic Chinese identity contrasts sharply with that of Malay identity, and is spelled out in specific Chinese cultural and religious associations and trade organisations, such as the Chinese Chamber of Commerce and Industry and other professional or non-professional organisations, mainly designed to serve ethnic Chinese interests. A somewhat negative consequence of this, is that the ethnic Chinese feel superior towards the Malay and Indian communities in terms of economic performance, but pragmatically recognise that the Malays in particular have the political power to impose their aspirations and ambitions on them, thus forcing them to support a status quo, as defined by the Malays.

An example of these ethnic Chinese organisations are the clan-based language groups. There are a variety of ethnic Chinese languages spoken in JB, unlike the situation in Manado in North Sulawesi, where Hokkian speaking Chinese predominate, representing about 85 percent of the population. In JB there are Teochius, Hokkians, Hainans, Hakka, and Cantonese-speaking Chinese in almost equal proportions. In this sense it looks like totoks prevail in this part of southern Malaysia. Representatives from these language groups mix, but are nonetheless divided into clans that provide each other with help when doing business amongst 
themselves, with bumiputra entrepreneurs, and when linking up to business contacts in Mainland China. In fact, all five language groups have formed their own associations. These are mostly social associations and not specifically oriented towards economic or political ends. These associations are interest groups, which means that they can exert pressure on politicians and parties alike by giving 'advice' about the needs and demands of the ethnic Chinese community. They maintain strong ties to Mainland China and see it their main concern to be to uphold the ties to the old country in terms of culture and language. They are especially active within the area of language, as many of the younger Chinese have problems speaking the various Chinese dialects or Mandarin.

As mentioned, the different clans are not exclusive. On the contrary, they inter-marry and initiate joint business ventures. There are, however, rather strained relations towards the bumiputra business community and the provincial and Malaysian state. The two are closely related - the former is explicitly supported by the latter, thus leaving the ethnic Chinese (and the Indians) more and less outside influence in this connection. Despite these constraints, there are business related joint ventures between the ethnic Chinese and bumiputra. This is actually necessary if ethnic Chinese entrepreneurs are interested in getting government contracts for major projects. Should the Chinese companies succeed in gaining government contracts, they have to have at least one Malay representative in the company's board of directors, as the law requires. Such arrangements are very similar to the Ali-baba arrangements in Indonesia.

The Cantonese association is the oldest one of the five 'clans'. It was founded in around 1880, and has been active ever since. The Hokkien association is the youngest. For many, especially older ethnic Chinese entrepreneurs in JB, guanxi affiliations are very important for governing interaction within and between firms. This applies particularly in relation to the work done within and between the language associations. Interestingly, the guanxi-governed associations do not automatically invite new migrants from Mainland China to settle down in JB even though they have quite close connections to Mainland China. If a newly arrived migrant who originates from, say, Guangdong, he would not necessarily have contacted the Cantonese association before leaving Mainland China. Generally, migration occurs on a personal initiative without the help of the association. The latter only becomes important when the new migrants have settled down in JB, as then the migrant may be invited to utilise the various networks of the Cantonese association. 
Guanxi practices are still important, not only within these associations, but also within the business community, a fact that is reinforced by a general perception of exclusion and social marginalisation. There are, however, different attitudes towards guanxi practices within the ethnic Chinese business community. In particular, it is among the older generation of entrepreneurs that guanxi affiliations are regarded as being very important, especially when initiating new business ventures. The initial meeting between new business partners, for example, is arranged along guanxi lines, that is, pre-organised by an intermediary that both parties trust.

This way of initiating and conducting business is not so prevalent among the younger generation of entrepreneurs. For them, Chinese entrepreneurs do not exist in a vacuum, as some of the older entrepreneurs still seem to think. They have to take account of the changing modes of doing business with the outside world - not only in relation to the Malaysian economy but also to the global one, strongly represented by Singapore just across the Johor Strait. Many young entrepreneurs regard a guanxi-dominated economy as a hindrance towards economic flexibility and a free flow of capital. Both of these economic premises are necessary when addressing the, at times, volatile fluctuations within the global economy. As a consequence, a rethinking of business practices within the ethnic Chinese business environment in JB is beginning, as stiff competition from, especially Singapore, combined with a braindrain of the best young entrepreneurs to Singapore, is on the rise, thus threatening the overall economic environment and performance in Johor Baru.

Interestingly, it is thus Singapore - and not Mainland China - that poses the greatest threat towards the small scale Chinese economy in JB, despite the fact that Singapore is also seen as a great source of income, especially in terms of consumer spending. Mainland China is perceived as an opportunity - not a threat or a must - that can be exploited if the opportunity to break into that market presents itself. This is due to the fact that most of JB's SME enterprises (both Chinese and non-Chinese) are multi-directional in their search for new markets that is, towards the domestic market, the important Singaporean market, and towards other East and Southeast Asian markets. ${ }^{15}$ 


\section{Mixing the 'China Factor' and Local Constraints}

One of the main purposes of this paper has been to assess the importance of the social and political attitudes towards the ethnic Chinese entrepreneurs in Southeast Asian countries within the shadow of Mainland China. The main focus has been on ethnic Chinese SME entrepreneurs, as they are more vulnerable in relation to the social and political whims of their respective communities of residence, than the ethnic Chinese controlled transnational conglomerates and large firms. The two latter are in a much stronger position to survive more or less problematic changes emanating from the political establishment in their respective communities of residence than the SMEs, as they are capable of moving their production lines and capital assets to other locations outside their Southeast Asian location if need be. Furthermore, conglomerates and larger firms are also more likely to follow the mainstream of international capital flows in order to maximise their output. In these cases, guanxi and xinyong together with other culture specific Chinese modes of doing business have little influence, as the rate of profitability within global capitalism carry much more weight ${ }^{16}$.

From a general perspective, South East Asian Chinese SMEs are more or less forced to comply with rules for conducting business that are in their communities of residence. This applies particularly when dealing with non-Chinese entrepreneurs. When doing business on an intraethnic basis, that is, with other ethnic Chinese entrepreneurs, guanxi and other culture specific Chinese modes of business practices have a much greater influence. This does not mean, however, that intra-ethnic business practices are exclusively conducted along culturally defined modes. On the contrary, as shown in particularly the Manado case, the culturally informed business practices constitute but one set of practices out of other business practices, when designing various intra- and interethnic business strategies.

The differences between SMEs and the large Chinese controlled firms and conglomerates are shown in their different attitudes towards the economic possibilities in Mainland China. As stipulated in the beginning of this paper, the economies that will benefit the most from China are those that can penetrate the growing Chinese market, develop complementary relations with the Chinese economy, attract investment from China, and develop partnerships with Mainland Chinese entrepreneurs. 
Large firms and conglomerates are more able of taking advantage of the opportunities offered by an expanding Mainland Chinese market by offering superior management expertise and technological knowhow, having access to huge amounts of capital and production assets, things that are much wanted by Mainland Chinese entrepreneurs and governmental development schemes. Furthermore, if the big companies prefer to stay on in Southeast Asia, but still want to enter the Mainland Chinese market, they also have an advantage compared to the SMEs, in that they are capable of conforming and changing their production base locally, so as to be able to meet the needs of Mainland Chinese investors. In this sense, Mainland China constitutes a major attraction.

These possibilities do not apply to SMEs in the same way, as they are more or less dependent on local conditions such as bumiputra policies in Malaysia and Ali-baba relationships, combined with negative stigmatisation in Indonesia. In order words, they are more dependent on contextual constraints. This also means that questions of integration and assimilation in relation to the host community, become more important and decisive for whether companies orient themselves towards Mainland China or the host community. In fact, there is not much choice. The local always prevails over the international, as the former is the one who provides the individual ethnic Chinese entrepreneur and his company with a framework within which to thrive - a framework that is not only constrained in terms of business opportunities, but also in terms of ethnicity and negotiated identities. On the basis of this, the market in Mainland China remains a distant, and possibly problematic, potential.

Michael Jacobsen is associate professor at Asia Research Centre, Copenhagen Business School (mj.int@cbs.dk).

\section{Notes}

1 Bloomberg News 12 January 2004.

2 Yeung 2006: 7-8.

3 For a general discussion, see Bolt 2000.

4 For further details, see Jacobsen 2005.

5 A short hand definition of guanxi is that it constitutes a form of social exchange based on sentiments and emotions and are marked by a mutual belief in reciprocity and loyalty.

6 Luo (2000), Yang (1994), Weidenbaum and Hughes (1996).

7 McKeown (2001), Bolt (2000) and Gipouloux (2000).

8 For a critical discussion of 'Confucian capitalism', see Yao 2002 and Dirlik 1996. 
Michael Jacobsen

9 For a discussion of the inner workings of the Chinese diaspora globally, see Ong and Nonini 1997.

10 For a fascinating discussion in this connection, see Ang (2001) and Riggs (2001).

11 Bolt 2000: 119-25, Yeung 2006: 14.

12 For further details, see Pan (1999: 157-60).

13 The Minahasa is the main ethnic group in North Sulawesi Province.

14 For more details, see Jacobsen 2006.

15 For further details, see Wee, Jacobsen, Wong 2006.

16 For a detailed account in this context, see Gomez et al. 2004.

\section{REFERENCES}

Ang, Ien 2001. On Not Speaking Chinese. Living Between Asia and the West. London: Routledge.

Tan, Chee Beng 1997. 'Comments on "Ethnic Chinese in Southeast Asia: Overseas Chinese, Chinese Overseas or Southeast Asians?"'. In Leo Suryadinata (ed.), Ethnic Chinese as Southeast Asians. Singapore: Institute of Southeast Asian Studies 1997: 25-32

Bolt, Paul J. 2000. China and Southeast Asia's Ethnic Chinese: State and Diaspora in Contemporary Asia. Westport: Praeger.

Callahan, William A. 2002. Diaspora, Cosmopolitanism and Nationalism: Overseas Chinese and Neo-nationalism in China and Thailand. Hong Kong: City University of Hong Kong, Southeast Asia Research Centre, Working Paper Series no. 35, November.

Cribb, Robert 2000. 'Political Structures and Chinese Business Connections in the Malay World: A Historical Perspective'. In Chan Kwok Bun (ed.) Chinese Business Networks. State, Economy and Culture. Singapore: Prentice Hall 2000: 176-92.

Dirlik, Arif 1996. 'Critical Reflections on "Chinese Capitalism" as a Paradigm'. In R. Ampalavanar Brown (ed.), Chinese Business Enterprise, Vol. I. London: Routledge 1996: 17-38.

Gipouloux, François 2000. 'Network and Guanxi: Towards an Informal Integration through Common Business Prectices in Greater China'. In Chan Kwok Bun (ed.) Chinese Business Networks. State, Economy and Culture. Singapore: Prentice Hall 2000: 57-70.

Gomez, Edmund T. 1999. Chinese Business in Malaysia. Accumulation, Ascendance, Accommodation. Surrey: Curzon Press.

Gomez, Edmund T. and Hsin-Huang Hsiao 2000. Chinese Business in Southeast Asia: Contesting Cultural Explanations, Researching Entrepreneurship. Richmond: Curzon Press.

Gomez, Edmund Terence and Gregor Benton 2004. 'Introduction: De-essentialising Capitalism: Chinese Enterprise, Transnationalism and Identity'. In Edmund Terence Gomez and Hsin-Huang Michael Hsiao (eds), Chinese Enterprise, Transnationalism and Identity. London: Routledge/Curzon 2004: 1-19.

Jacobsen, Michael 2005. 'Islam and Processes of Minorisation among Ethnic Chinese in Indonesia: Oscillating between Faith and Political Economic Expediency'. Asian Ethnicity 6(2), June: 71-87.

- 2006. 'Doing Business the Chinese Way? On Manadonese Chinese Entrepreneurship in North Sulawesi'. Copenhagen Journal of Asian Studies 24: 72-104.

Kotkin, Joel 1992. Tribes: How Race, Religion, and Identity Determine Success in the New Global Economy. New York: Random House.

Luo, Yadong 2000. Guanxi and Business. Singapore: World Scientific. 
McKeown, A. 2001. Chinese Migrant Networks and Cultural Change: Peru, Chicago, Hawaii, 1900-1936. Chicago: The University of Chicago Press.

Ong, Aiwa and Donald M Nonini. 1997. Ungrounded Empires. The Cultural Politics of Modern Chinese Transnationalism. New York: Routledge.

Pann, Lyn (ed.) 1999. The Encyclopedia of the Chinese Overseas. Surrey: Curzon Press.

Pangestu, Mari 2002. 'China and Southeast Asian Regional Trade Cooperation: Trends and Perspectives'. International Conference Paper on East Asian Cooperation: Progress and Future Agenda. Hosted by the Institute of Asia-Pacific Studies (IAPS), CASS. Center for APEC and East Asia Cooperation (CAEAC), CASS. 22-23 August. Beijing.

Qiu, Liben 2000. 'The Chinese Networks in Southeast Asia: Past, Present and Future'. In Chan Kwok Bun (ed.) Chinese Business Networks. State, Economy and Culture. Singapore: Prentice Hall 2000: 193-206.

Riggs, Fred W. 2001. Glocalization, Diaspora and Area Studies, pp. 1-4, <http://www2. hawaii.edu/fredr/glocal.htm>

Skinner, G. William 1996. 'Creolized Chinese Societies in Southeast Asia'. In Anthony Reid (ed.), Sojourners and Settlers. Histories of Southeast Asia and the Chinese. North Sydney: Allen \& Unwin 1996: 51-93.

Suryadinata, Leo 1997. 'Ethnic Chinese in Southeast Asia: Overseas Chinese, Chinese Overseas or Southeast Asians?'. In Leo Suryadinata (ed.), Ethnic Chinese as Southeast Asians. Singapore: Institute of Southeast Asian Studies 1997: 1-24.

Tan, Mely G. 1997. 'The Ethnic Chinese in Indonesia: Issues of Identity'. In Leo Suryadinata (ed.), Ethnic Chinese as Southeast Asians. Singapore: Institute of Southeast Asian Studies 1997: 33-65.

Wanandi, Jusuf 2002. 'The rise of China: A Challenge for East Asia'. The Indonesian Quarterly XXX (3) Third Quarter: 224-33.

Wee, Vivienne, Michael Jacobsen, Tiong Chong Wong 2006. 'Positioning Strategies on Southeast Asian Chinese Entrepreneurs'. Journal of Contemporary Asia 36 (3).

Weidenbaum, Murray L. and Samuel Hughes 1996. TheBamboo Network - How expatriate Chinese entrepreneurs are creating a new economic superpower in Asia. London: The Free Press.

Wong, J. 1998. Southeast Asian Ethnic Chinese Investing in China. Singagpore: East Asian Institute, National University of Singapore, Working Paper No. 15.

Yang, Mei-hui 1994. Gifts, Favours, and Banquets: The Art of Social Relationships in China. Ithaca: Cornell University Press.

Yao, Souchou 2002 Confucian Capitalism. Discourse, Practive and the Myth of Chinese Enterprise. New York: Routledge/Curzon Press.

Yeung, Henry W.C. 2006. 'Change and Continuity in Southeast Asian Ethnic Chinese Business'. Asia Pacific Journal of Management 23(3): 229-54. 